\title{
Epidemiological Follow-up 15 Years after the Breast Cancer Scandal in Essen
}

\section{Epidemiologische Verlaufskontrolle 15 Jahre nach dem Brustkrebsskandal in Essen}

Authors

Affiliations
E. A. M. Hauth ${ }^{1,3}$, S. Berkemeyer ${ }^{2}$, H. Jaeger ${ }^{1}$, M. Forsting ${ }^{3}$, B. Hoffmann ${ }^{4}$, K.-H. Jöckel ${ }^{2}$

${ }^{1}$ Radiologische Gemeinschaftspraxis, Ulm

${ }^{2}$ Institut für Medizinische Informatik, Biometrie und Epidemiologie, Universitätsklinikum Essen, Essen

3 Institut für Diagnostische und Interventionelle Radiologie und Neuroradiologie, Universitätsklinikum Essen, Essen

${ }^{4}$ Arbeitsbereich Epidemiologie, IUF Leibniz-Institut für umweltmedizinische Forschung, Heinrich Heine Universität Düsseldorf
Key words

- follow-up

- breast cancer

- survival rate

- tumour recurrence

Schlüsselwörter

- Verlaufskontrolle

- Mammakarzinom

- Überlebensrate

- Tumorrezidiv received 18.4.2011

revised 29.11.2011

accepted 30.3.2012

\section{Bibliography}

DOI http://dx.doi.org/ 10.1055/s-0031-1298541

Geburtsh Frauenheilk 2012; 72 :

513-522 @ Georg Thieme

Verlag KG Stuttgart - New York ISSN 0016-5751

\section{Correspondence}

Priv.-Doz. Dr. med. Elke Hauth

Radiologische

Gemeinschaftspraxis

Parkstraße 10

89073 Ulm

ehauth@t-online.de

\section{Abstract}

$\nabla$

Purpose: In the years 1993-1996 a number of presumably false-positive breast cancer diagnoses were made by a pathologist in Essen. A follow-up, undertaken 15 years later, investigated how many women had tumour recurrence and/ or metastasis or had died from breast cancer.

Material and Methods: A total of 151 (68\%) out of 222 women could be traced. One hundred and forty-seven (66.2\%) of the 222 women were alive. The observed survival rate, number of recurrences and/or metastases, and number of deaths from breast cancer were compared with data from the Munich Tumour Registry. The number of breast cancer cases among daughters of the affected women was ascertained.

Results: The total observed survival rate at follow-up after 15 years was $93 \%$, a much higher figure than the survival rate of $45 \%$ given by the $\mathrm{Mu}$ nich Tumour Registry. Recurrence and/or metastasis or death from breast cancer occurred in 9/ 222 cases (4.1\%). The incidence for these events calculated according to data from the Munich Tumour Registry is $13 \%$. Two daughters $(2.2 \%)$ out of a total of 90 were diagnosed with breast cancer whereas, according to the German Cancer Research Centre, the expected rate would have been between 5 and $10 \%$.

Conclusions: The results of our follow-up after 15 years show that more women survived than expected and that the number of recurrences and/ or metastases and deaths due to breast cancer was lower than expected. Fewer daughters of affected women were diagnosed with breast cancer than expected. These results support our suspicion that not all women diagnosed with breast cancer by a pathologist in Essen actually had breast cancer.

\section{Zusammenfassung \\ $\nabla$}

Ziel: Durch einen Pathologen in Essen wurden 1993-1996 vermutlich falsche Brustkrebsdiagnosen gestellt. In einer Verlaufskontrolle nach 15 Jahren wurde untersucht, wie viele Frauen an einem Tumorrezidiv und/oder Metastasen erkrankt oder an Brustkrebs verstorben sind.

Material und Methoden: Bei 151/222 (68\%) Frauen war eine Verlaufsdokumentation möglich. 147/222 (66,2\%) Frauen lebten. Die Überlebensrate und die beobachtete Zahl von Rezidiven und/oder Metastasen und Tod durch Mammakarzinom wurden mit denen des Tumorregisters München verglichen. Die Anzahl der aufgetretenen Mammakarzinome bei den Töchtern der Betroffenen wurde ermittelt.

Ergebnisse: In der 15-Jahres-Verlaufskontrolle betrug die beobachtete Gesamtüberlebensrate 93\% und war somit höher als das Überleben von $45 \%$ nach dem Tumorregister München. Bei 9/ 222 (4,1\%) wurden Rezidive und/oder Metastasen oder Tod durch Mammakarzinom beobachtet. Diese Ereignisse wären nach dem Tumorregister München mit einer Häufigkeit von 13\% aufgetreten. 2/90 (2,2\%) Töchter erkrankten an einem Mammakarzinom, wonach nach dem Deutschen Krebsforschungszentrum eine Anzahl zwischen 5-10\% zu erwarten gewesen wären.

Schlussfolgerungen: Die Ergebnisse unserer 15Jahres-Verlaufskontrolle zeigen, dass mehr Frauen überlebt haben als erwartet und dass die Anzahl an Rezidiven und/oder Metastasen und Tod durch Mammakarzinom geringer war als erwartet. Es waren weniger Töchter der betroffenen Frauen an einem Mammakarzinom erkrankt als erwartet. Diese Ergebnisse unterstützen die Vermutung, dass nicht alle Frauen bei Diagnosestellung durch den Pathologen in Essen an einem Mammakarzinom erkrankt waren. 


\section{Introduction}

In the years 1993-1996 a number of presumably false-positive breast cancer diagnoses were made in Essen by a pathologist (Prof. Dr. Kemnitz). The suspicion that these diagnoses were false-positive arose because the data showed unusually high numbers of women with early stage breast cancer in Essen. Based on this information, a gynaecologist requested that the pathologist hand over tissue samples of his patients for re-examination by a second specialist. Examination confirmed the suspicion of wrongful breast cancer diagnoses. A charge was brought against the pathologist for bodily injury caused by negligence. In 1997 the pathologist set fire to his laboratory and lost his own life in the blaze. Numerous tissue samples of patients were incinerated and so were not available as evidence. The number of women affected was estimated to be around 300. It has still not been possible to find out exactly how many women were affected [1].

The women can therefore not discover whether they actually had breast cancer or not. A statement issued in 2000 by the German Society for Senology confirmed the suspicion that not all of the women had breast cancer and that some of them had been victims of a false diagnosis [2].

The aim of this study was to investigate, through personal questioning of the affected women 15 years after the breast cancer study, how many of these women had tumour recurrence or metastasis or had died of breast cancer. A comparison was made with the previous 10-year follow-up [1]. In addition, this study also investigated how many of the women had given birth to a daughter and how many of these daughters had been diagnosed with breast cancer.

\section{Patients and Methods}

$\nabla$

10-year follow-up

A total of 222 women whose data was on record were sent a written request to present themselves for their 10-year follow-up. Documentation was available for 171 women. At the time of the 10-year follow-up 7 of the 171 women had died, 2 of whom had died from breast cancer. At the time of the 10-year follow-up, 164 women were alive. Ten of the 164 women did not wish to participate but had not experienced recurrence of breast cancer or metastasis. A total of 154 women participated in the 10-year followup investigation [1].

A total of 76 (49.4\%) out of 154 women had undergone mastectomy; 78 (50.6\%) of 154 cases had had breast-conserving therapy.

Table 1 Diagnosed tumour stages (from [1]).

\begin{tabular}{|lll|}
\hline TNM stage & $\begin{array}{l}\text { Affected breast, } \\
\mathbf{n = 1 2 9}\end{array}$ & $\begin{array}{l}\text { Contralateral breast, } \\
\mathbf{n = 2 4}\end{array}$ \\
& $\mathbf{n}(\%)$ & $\mathbf{n}(\%)$ \\
\hline pTis N0 M0 & $25(19.4)$ & $7(29.2)$ \\
\hline PT1a N0 M0 & $25(19.4)$ & $3(12.5)$ \\
PT1b N0 M0 & $30(23.2)$ & $5(20.8)$ \\
PT1c N0 M0 & $8(6.2)$ & $1(4.2)$ \\
\hline PT2 N0 M0 & $4(3.1)$ & $2(8.3)$ \\
\hline PT1 N1 M0 & $31(24.0)$ & $6(25.0)$ \\
\hline PT2 N1 M0 & $6(4.7)$ & $0(0)$ \\
\hline
\end{tabular}

The tumour stage of the affected breast could be ascertained in 129 of 154 cases. The tumour stage could be determined in 24 of 37 patients with malignant findings in the contralateral breast.

\section{Einleitung

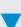

In den Jahren 1993-1996 wurden in Essen durch einen Pathologen (Prof. Dr. Kemnitz) vermutlich falsche Brustkrebsdiagnosen gestellt. Dieser Verdacht entstand dadurch, dass eine starke Häufung von Frühstadien des Mammakarzinoms in Essen aufgefallen war. Ein niedergelassener Gynäkologe verlangte daraufhin von dem Pathologen die Herausgabe der Gewebeproben seiner Patientinnen zur Zweitbegutachtung. Diese bestätigte den Verdacht der falschen Brustkrebsdiagnosen. Es erfolgte die Anklage des Pathologen wegen fahrlässiger Körperverletzung. Dieser setzte schließlich 1997 sein Labor in Brand und kam dabei ums Leben. In dem Feuer verbrannte auch eine Vielzahl der Gewebeproben der Patientinnen, sodass diese nicht mehr für eine Beweisführung verwendet werden konnten. Die Anzahl der betroffenen Frauen wird auf ca. 300 geschätzt. Die genaue Anzahl der Frauen ist bis heute jedoch unbekannt [1].

Somit konnten die Frauen nicht mehr klären, ob sie an Brustkrebs erkrankt waren oder nicht. In einer Stellungnahme der Deutschen Gesellschaft für Senologie im Jahre 2000 erhärtete sich der Verdacht, dass nicht alle Frauen an Brustkrebs erkrankt waren, sondern Opfer von Falschdiagnosen geworden waren [2].

Ziel der vorliegenden Arbeit war, durch eine persönliche Befragung der betroffenen Frauen 15 Jahre nach dem Brustkrebsskandal zu ermitteln, wie viele Frauen an einem Tumorrezidiv und/ oder Metastasen erkrankt oder an Brustkrebs verstorben sind. Es erfolgte der Vergleich mit der zuvor durchgeführten 10-Jahres-Verlaufskontrolle [1]. Zusätzlich wurde in dieser Arbeit ermittelt, wie viele der Frauen Töchter geboren hatten und wie viele der Töchter an einem Mammakarzinom erkrankt sind.

\section{Patientinnen und Methoden}

$\nabla$

10-Jahres-Verlaufskontrolle

222 aktenkundige, betroffene Frauen wurden 2005 schriftlich zur 10-Jahres-Verlaufskontrolle eingeladen. Bei 171 Frauen war eine Dokumentation des Verlaufs möglich. 7/171 waren zum Zeitpunkt der 10-Jahres-Verlaufskontrolle verstorben, davon 2 Frauen an den Folgen eines Mammakarzinoms.164 Frauen lebten zum Zeitpunkt der 10-Jahres-Verlaufskontrolle. 10/164 Frauen wollten nicht teilnehmen, hatten aber kein Rezidiv oder Metastasen eines Mammakarzinoms. 154 Frauen hatten an der 10-JahresVerlaufskontrolle teilgenommen [1].

Bei 76/154 (49,4\%) Frauen erfolgte eine Ablatio mammae, in 78/ 154 (50,6\%) Fällen erfolgte eine brusterhaltende Therapie. Das diagnostizierte Tumorstadium der betroffenen Brust konnte in 129/154 (83,7\%) Fällen und in 24/37 (65\%) der malignen Befunde der gegenseitigen Brust dokumentiert werden. Bei 63/154 $(48,8 \%)$ Frauen wurde für die betroffene Brust das Stadium pT1 (a, b, c) N0 M0 diagnostiziert. In 25 (19,4\%) Fällen wurde für die betroffene Brust ein In-situ-Karzinom (pTis) diagnostiziert. Folglich hatten 88/154 (68,2\%) Frauen ein pT1 und pTis-Stadium (๑ Tab. 1) [1].

Bei 7/164 (4,3\%) Frauen lagen in der 10-Jahres-Verlaufskontrolle ein Tumorrezidiv/Metastasen vor. Davon lagen bei 5/164 (3\%) Fällen ein Lokalrezidiv vor und in einem Fall ein kontralaterales Mammakarzinom. In 2 Fällen traten Metastasen des vermuteten Mammakarzinoms auf. Bei einer dieser Patientinnen mit Metastasierung lag bereits vorher ein Lokalrezidiv vor ( Tab. 2) [1]. 
Table 2 Characteristics of patients with tumour recurrence and/or metastasis, $\mathrm{n}=7$ (modified in accordance with [1]).

\begin{tabular}{|c|c|c|c|c|c|c|c|c|c|}
\hline $\begin{array}{l}\text { Pat. } \\
\text { No. }\end{array}$ & $\begin{array}{l}\text { Year } \\
\text { of OP }\end{array}$ & $\begin{array}{l}\text { Ipsilateral } \\
\text { operation }\end{array}$ & $\begin{array}{l}\text { Ipsilateral } \\
\text { TNM }\end{array}$ & $\begin{array}{l}\text { Year of con- } \\
\text { tralateral } \\
\text { OP }\end{array}$ & $\begin{array}{l}\text { Contralateral } \\
\text { operation }\end{array}$ & $\begin{array}{l}\text { Contra- } \\
\text { lateral } \\
\text { TNM }\end{array}$ & $\begin{array}{l}\text { Interval to } \\
\text { ipsilateral } \\
\text { recurrence } \\
\text { (years) }\end{array}$ & $\begin{array}{l}\text { Interval to } \\
\text { contralateral } \\
\text { recurrence } \\
\text { (years) }\end{array}$ & $\begin{array}{l}\text { Interval to } \\
\text { metastasis } \\
\text { (years) }\end{array}$ \\
\hline 1 & 1994 & mastectomy & pT1a N0M0 & 1994 & excision biopsy & - & 3 & -- & -- \\
\hline 2 & 1994 & mastectomy & PT1 N1 M0 & 1994 & mastectomy & PT1N0M0 & 1 & -- & -- \\
\hline 3 & 1994 & mastectomy & n.k. & 1995 & excision biopsy & - & 3 & -- & 11 \\
\hline 4 & 1993 & mastectomy & pT2 N1 M0 & 1994 & excision biopsy & - & 7 & -- & -- \\
\hline 5 & 1994 & BET & pT1b N0 M0 & - & - & - & 6 & -- & -- \\
\hline 6 & 1994 & mastectomy & pT1 N1 M0 & 1994 & excision biopsy & - & -- & -- & $11^{*}$ \\
\hline 7 & 1994 & mastectomy & n.k. & - & - & - & -- & 11 & -- \\
\hline
\end{tabular}

n. k. = not known, - = no operation, - - = no recurrence, no metastasis.

Ipsilateral is defined as the affected breast; contralateral is defined as the other breast.

* Died in the interval between the 10-year follow-up and the 15-year follow-up.
The diagnosed tumour stage of the affected breast was documented in $129 / 154(83.7 \%$ ) cases and in $24 / 37$ (65\%) women with malignant findings in the other breast. Tumour stage pT1 (a, b, c) NO M0 was diagnosed in the affected breast in 63/154 (48.8\%) women. Twenty-five (19.4\%) women were diagnosed with an in-situ carcinoma (pTis) in the affected breast. Thus 88/ 154 (68.2\%) women had stage pT1 and pTis ( Table 1) [1].

Tumour recurrence/metastasis was found in 7 (4.3\%) of 164 women at 10-year follow-up. Of these cases, 5/164 (3\%) had local recurrence and one woman had breast cancer in the contralateral breast. Two cases had metastasis of the presumed breast cancer. One of the patients with metastasis had presented previously with local recurrence ( $\odot$ Table 2 ) [1].

\section{5-year follow-up}

The 15-year follow-up in 2010 was done by telephone interview of the affected women. Data recorded included whether tumour recurrence and/or metastasis had occurred. If the woman had died the cause of death was determined through the questioning of family members. The number of daughters and their ages were recorded. The number of daughters who had been diagnosed with breast cancer was noted. In addition, the women were asked whether they had received any financial compensation.

\section{Definitions}

With regard to ipsilateral and contralateral local tumour manifestations which developed during the follow-up period it was assumed, in view of the diagnosis of breast cancer that had been made and for epidemiological analysis, that all of these cases were tumour recurrences. Similarly, metastases which developed during follow-up were attributed to the primary diagnosis of breast cancer.

Tumour progression was defined as the development of tumour recurrence or metastasis or death due to breast cancer.

\section{Statistical analysis}

The first analysis calculated the total probability of survival for the women investigated in this study at 15- and 10-year followup. This data was then compared with figures from the Munich Tumour Registry $[3,4]$. This analysis was expanded further by the additional calculation of survival probabilities for specific tumour stages. For this, the distribution of tumour stage-specific survival probabilities of the Munich Tumour Registry [4] was used to estimate the tumour stage-specific survival probability

\section{5-Jahres-Verlaufskontrolle}

Bei der 15-Jahres-Verlaufskontrolle erfolgte 2010 eine telefonische Befragung der betroffenen Frauen. Es wurde erfasst, ob Tumorrezidive und/oder Metastasen aufgetreten sind. Im Todesfall wurde die Todesursache durch ein Gespräch mit Angehörigen eruiert. Die Anzahl der Töchter und deren Alter wurden erfasst. Die Anzahl der Töchter, die an einem Mammakarzinom erkrankt waren, wurden dokumentiert. Darüber hinaus wurden die Frauen befragt, ob eine finanzielle Entschädigung erfolgt ist.

\section{Definitionen}

Hinsichtlich der im Verlauf aufgetretenen ipsilateralen und kontralateralen lokalen Tumormanifestationen wurden in Hinblick auf die bereits erfolgten Brustkrebsdiagnosen und für die epidemiologischen Analysen angenommen, dass es sich in allen Fällen um Tumorrezidive handelte. Ebenso wurden Metastasen, die im Verlauf aufgetreten waren, auf die primäre Brustkrebsdiagnose zurückgeführt.

Tumorprogression wurde definiert als Auftreten von Tumorrezidiven oder Metastasen oder Tod, verursacht durch das Mammakarzinom.

\section{Statistische Auswertung}

In der ersten Analyse erfolgte die Berechnung der in dieser Studie beobachteten Gesamtüberlebenswahrscheinlichkeit der betroffenen Frauen für 15 und 10 Jahre Follow-up. Diese wurde mit den Angaben des Tumorregisters München verglichen [3,4]. In einem weiteren Schritt wurde diese Analyse durch weitere Berechnungen von tumorstadienspezifischen Überlebenswahrscheinlichkeiten vertieft. Hierzu wurde die Verteilung der tumorstadienspezifischen Überlebenswahrscheinlichkeit des Tumorregisters München [4] benutzt, um die tumorstadienspezifische Überlebenswahrscheinlichkeit unserer Probe abzuschätzen. Dies wurde dann mit der tatsächlich beobachteten Überlebenswahrscheinlichkeit der betroffenen Frauen in Essen verglichen. Die Tumorstadienverteilung des Tumorregisters München betrug 50,1\% für das pT1-Stadium. Für unser Kollektiv war anzunehmen, dass die erhöhte Anzahl von Tumordiagnosen durch eine erhöhte Diagnose von früheren Stadien (pT1) erfolgte. Daher wurden 2 weitere Simulationen, für den Anteil von pT1 von 55 und 70\% vorgenommen.

In einer 2. Analyse erfolgten die Berechnung der Progression der betroffenen Frauen und der Vergleich mit der Progression des Tumorregisters München. Hierzu ermittelte das Tumorregister 
for our sample. This was then compared with the actually observed survival of the affected women in Essen. The distribution of tumour stages according to the Munich Tumour Registry was $50.1 \%$ for the pT1 stage. For our collective we assumed that the increased number of tumour diagnoses were the result of an increased number of diagnoses of early stage tumours (pT1). Therefore 2 further simulations were done using higher rates for pT1 tumour diagnosis of 55 and $70 \%$, respectively.

In a second analysis, disease progression of the affected women was compared with progression calculated using data from the Munich Tumour Registry. According to the Munich Tumour Registry, over a period of 29 years approximately $25 \%$ of women diagnosed with breast cancer will show progression (out of a total of 34478 women, 8621 had disease progression over a period of 29 years). Calculated for a 15 -year period, this would result in a disease progression rate of $13 \%$, and we used this figure as the basis for our analysis. In addition, we did a sensitivity analysis where we assumed that all of the women we were unable to reach or who did not participate had suffered disease progression or had died.

In a third analysis, the incidence of breast cancer among the daughters of the affected women was calculated. The figures for the incidence of breast cancer in the daughters was compared with figures from the literature $[5,6]$. In a second step, the incidence of breast cancer reported in the Cancer Registry of NorthRhine Westphalia (1994 to 2008) was used to retrospectively estimate the expected cumulated incidence of breast cancer occurring in daughters for the years 1996 to 2010 and for the different age groups. To allow for the expected increased incidence in cases with a positive familial diagnosis, the expected calculated cumulated incidence was increased by $10 \%$. Finally, these expected figures were compared with the actual numbers reported for the collective of affected women.

Data analysis was carried out using Microsoft ${ }^{\circledR}$ Excel 2007 (Microsoft Corporation, WA, USA) and SAS (Version 9.2, SAS Institute, Cary, NC, USA).

\section{Results}

$\nabla$

Three of 154 women who had participated in the 10-year followup in 2005 could not be contacted for the 15-year follow-up and none of their families could be contacted. Thus, follow-up was possible for 151 (68\%) of the previous 222 women on record. Four of 151 women had died by this time. One of the 4 died due to breast cancer metastasis. This woman had already had metastasis at the 10-year follow-up. According to reports given by family members, 2/4 women died from cardiac insufficiency and one woman died due to a brain tumour. One hundred and forty-seven women were still alive and participated in the 15-year follow-up.
München, dass über 29 Jahre ca. 25\% der Brustkrebserkrankten eine Progression zeigten (von 34478 Frauen hatten 8621 eine Progression über 29 Jahren). Berechnet auf eine Zeitperiode von 15 Jahren ergab sich damit eine Progression von 13\%, die als Vergleich für unsere Analyse herangezogen wurde. Darüber hinaus wurde im Rahmen einer Sensitivitätsanalyse angenommen, dass alle nicht erreichten bzw. teilgenommenen Frauen eine Progression erlitten hatten bzw. verstorben waren.

In einer 3. Analyse wurde die Häufigkeit des Auftretens von Mammakarzinomen bei den Töchtern der erkrankten Frauen ermittelt. Der beobachtete Anteil der Mammakarzinome bei den Töchtern wurde mit den Zahlen aus der veröffentlichten Literatur verglichen [5,6]. In einem 2. Verfahren wurde die Inzidenz des Mammakarzinoms aus dem Krebsregister NRW (1994-2008) benutzt, um die erwartete kumulierte Inzidenz des Mammakarzinoms bei den Töchtern, rückwirkend für die Jahre 1996 bis 2010 und für die jeweiligen Altersgruppen, einzuschätzen. Um der erwarteten Erhöhung der Inzidenz bei Vorliegen einer positiven Familienanamnese Rechnung zu tragen, wurde die so erhaltene erwartete kumulierte Inzidenz um 10\% erhöht. Schließlich erfolgte der Vergleich dieser erwarteten Fälle mit den beobachteten Fällen in dem Kollektiv der betroffenen Frauen.

Die Datenanalyse erfolgte mit dem Microsoft ${ }^{\circledR}$ Excel 2007 (Microsoft Corporation, WA, USA) und SAS (Version 9.2, SAS Institute, Cary, NC, USA).

\section{Ergebnisse}

$\nabla$

3/154 Frauen, welche 2005 an der 10-Jahres-Verlaufskontrolle teilnahmen, konnten zur 15-Jahres-Verlaufskontrolle nicht mehr kontaktiert werden, oder es konnten keine Angehörigen erreicht werden. Damit war bei 151 der ursprünglich aktenkundigen 222 (68\%) Frauen eine Dokumentation des Verlaufs möglich. 4/151 Frauen waren zwischenzeitig verstorben. Eine der 4 Frauen verstarb an einer Metastase eines Mammakarzinoms. Diese Frau hatte bereits in der 10-Jahres-Verlaufskontrolle eine Metastase. 2/4 Frauen starben nach Angaben der Familienmitglieder an Herzversagen und eine Frau an einem Hirntumor. 147 Frauen lebten und haben an der 15-Jahres-Verlaufskontrolle teilgenommen. Ebenso lebten die 6/7 Frauen mit Tumorprogression in der 10-Jahres-Verlaufskontrolle noch zum Zeitpunkt der 15-JahresVerlaufskontrolle (๑ Tab. 2).

- Tab. 3 zeigt einen Überblick über die Anzahl der Patientinnen in der 10-Jahres-Verlaufskontrolle und 15-Jahres-Verlaufskontrolle.

Table 3 Number of patients who participated in the 10-year follow-up and the 15-year follow-up.

\begin{tabular}{|c|c|c|c|c|c|c|}
\hline Year & $\begin{array}{l}\text { Total } \\
\text { number }\end{array}$ & $\begin{array}{l}\text { Documentation } \\
\text { possible }\end{array}$ & Alive & Dead & $\begin{array}{l}\text { Participated } \\
\text { in study }\end{array}$ & Lost to follow-up \\
\hline 1993-1996 & 222 & & 222 & - & - & - \\
\hline 10-year follow-up in 2005 & 222 & 171 & 164 & 7 & 154 & 51 \\
\hline 15-year follow-up in 2010 & 222 & 151 & 147 & 4 & 147 & $13^{*}$ \\
\hline Net figure for 2010 & 222 & & 147 & 11 & 147 & 64 \\
\hline
\end{tabular}

* 13 = comprises 3 women who could not be contacted for the 15-year follow-up and 10 women out of 164 surviving women from the 10 -year follow-up who preferred not to be contacted any more in the future. 
Six of the 7 women with disease progression at the 10-year follow-up were still alive at the 15 -year follow-up ( $\bullet$ Table 2 ).

- Table 3 shows the numbers of patients who participated in the 10-year and 15-year follow-up.

\section{Mortality at 15-year follow-up}

- Table 4 shows the actual total survival at the 10-year and 15year follow-up. If we take the original figure of 222 women on record and the figure of 154 women who were alive at the 10-year follow-up, subtracting the 51 women about whom no information was available, the recorded total survival rate after 10 years was $95.9 \%$. With regard to the 15 -year follow-up and again taking the original number of 222 women into consideration, the total survival rate after 15 years after subtraction of the 64 women about whom no information was available was 93.0\% ( Table 4). If we make a conservative assumption that all the women about whom we have no information and who therefore were not followed up after 10 and 15 years all died, we could expect a total survival rate of $73.9 \%$ after 10 years and of $66.2 \%$ after 15 years (Simulation 1 and 3 in 0 Table 4).

By comparison, the 10-year survival rate according to the field study of the Munich Tumour Registry was 59\% and the survival rate after 15 years was $45 \%$ ( Table 5). Compared to the Munich Tumour Registry the total survival rate for the women in our study after 10 and 15 years - even when we assumed the worst prognosis - was therefore 14.9 percentage points (73.9 vs. $59 \%$ ) and 21.2 percentage points (66.2 vs. $54 \%$ ) higher ( Table 5 ).

The results of our analysis of survival probability (total survival) after 15 years according to the distribution of tumour stages at first diagnosis using the Munich field study are shown in - Fig. 1. The observed total survival of 147 affected women thus clearly exceeded the expected figure of 99 women.

\section{Mortalität in der 15-Jahres-Verlaufskontrolle}

- Tab. 4 zeigt das beobachtete Gesamtüberleben in der 10-Jahres-Verlaufskontrolle und 15-Jahres-Verlaufskontrolle. Unter Berücksichtigung der ursprünglich 222 aktenkundigen Frauen und der in der 10-Jahres-Verlaufskontrolle 154 lebenden Frauen ergibt sich nach Subtraktion der 51 Frauen, von denen wir keine Informationen haben, ein beobachtetes Gesamtüberleben nach 10 Jahren von 95,9\%. Bezüglich der 15-Jahres-Verlaufskontrolle ergibt sich unter Berücksichtigung der ursprünglich 222 aktenkundigen Frauen und der 147 lebenden Frauen nach Subtraktion der 64 Frauen, von denen wir keine Informationen haben, ein beobachtetes Gesamtüberleben nach 15 Jahren von 93,0\% (๑ Tab. 4).

Unter der konservativen Annahme, dass die Frauen, bei denen wir keine Informationen haben und folglich keine 10-Jahresund keine 15-Jahres-Verlaufskontrolle möglich war, alle verstorben sind, wäre nach 10 Jahren ein Gesamtüberleben von 73,9\% und nach 15 Jahren ein Gesamtüberleben von 66,2\% zu erwarten gewesen (Simulation 1 und 3 in $\bigcirc$ Tab. 4).

Im Vergleich hierzu liegt die 10-Jahres-Überlebensrate nach der Feldstudie des Tumorregisters München bei 59\% und nach 15 Jahren bei 45\% ( Tab. 5). Im Vergleich zum Tumorregister München ist das Gesamtüberleben unserer Frauen nach 10 und 15 Jahren auch bei der schlechtesten Prognose demnach 14,9 Prozentpunkte (73,9 vs. 59\%) bzw. 21,2 Prozentpunkte (66,2 vs. 54\%) höher ( Tab. 5).

Die Ergebnisse der Analyse der Überlebenswahrscheinlichkeit (Gesamtüberleben) nach 15 Jahren bei einer der Feldstudie München entsprechenden Stadienverteilung bei Erstdiagnose sind in - Abb. 1 dargestellt. Das beobachtete Gesamtüberleben von mindestens 147 betroffenen Frauen übertraf damit deutlich die erwartete Anzahl von 99 Frauen.

Table 4 Total survival as observed in the study for 2005 and 2010.

\begin{tabular}{|c|c|c|c|}
\hline 10-year follow-up in 2005 & & 15-year follow-up in 2010 & \\
\hline Affected women (n) & 222 & Affected women (n) & 222 \\
\hline Alive (n) & 164 & Alive $(n)$ & 147 \\
\hline Dead (n) & 7 & Dead (n) & 11 \\
\hline Lost to follow-up (n) & 51 & Lost to follow-up (n) & 64 \\
\hline Observed total survival (\%) & $95.9 \%$ & Observed total survival (\%) & $93.0 \%$ \\
\hline $\begin{array}{l}\text { Simulation 1: The } 51 \text { women lost to follow-up } \\
\text { all died: simulated survival } 1\end{array}$ & $73.9 \%$ & $\begin{array}{l}\text { Simulation 3: The } 64 \text { women lost to follow-up } \\
\text { all died: simulated survival } 1\end{array}$ & $66.2 \%$ \\
\hline $\begin{array}{l}\text { Simulation 2: The } 51 \text { women lost to follow-up } \\
\text { are all still alive: simulated survival } 2\end{array}$ & $96.8 \%$ & $\begin{array}{l}\text { Simulation 4: The } 64 \text { women lost to follow-up } \\
\text { are all still alive: simulated survival } 2\end{array}$ & $95 \%$ \\
\hline
\end{tabular}

10 years: $(164$ alive $) /(222$ women with breast cancer -51 lost to follow-up $) \times 100=95.9 \%$

15 years: $(147$ alive $) /(222$ women with breast cancer -64 lost to follow-up $) \times 100=93.0 \%$

General formula:

Survival rate $=($ alive at the point in time $\mathrm{x}) /($ original total number of investigated cases - cases about whom no information could be obtained $) \times 100$

Table 5 Total observed survival compared to the results of the Munich field study cohort*.

\begin{tabular}{|c|c|c|c|c|}
\hline \multirow{2}{*}{\multicolumn{2}{|c|}{ Survival according to the Munich Tumour Registry }} & \multicolumn{3}{|c|}{ Survival observed in this study } \\
\hline & & Actual survival & Best prognosis & Worst prognosis \\
\hline After 10 years & $59 \%$ & $95.9 \%$ & $96.8 \%^{a}$ & $73.9 \%^{b}$ \\
\hline After 15 years & $45 \%$ & $93.0 \%$ & $95.0 \%{ }^{c}$ & $66.2 \% d$ \\
\hline
\end{tabular}

* Based on the Munich Tumour Registry - Specific survival analysis for breast cancer, 2005, Data analysis of the field study of the Tumour Registry $1988-1995$.

a Simulation 2, cf. $\odot$ Table 4

b Simulation 1, cf. ๑ Table 4

c Simulation 4, cf. ๑ Table 4

d Simulation 3, cf. ๑ Table 4 


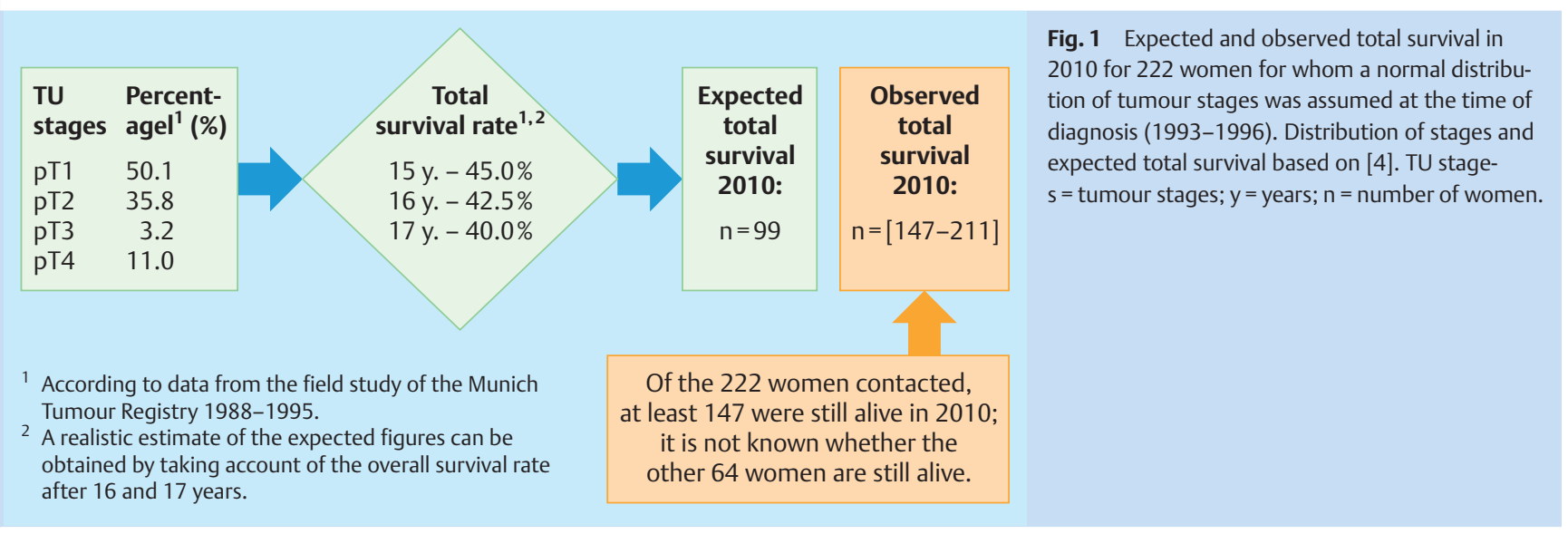

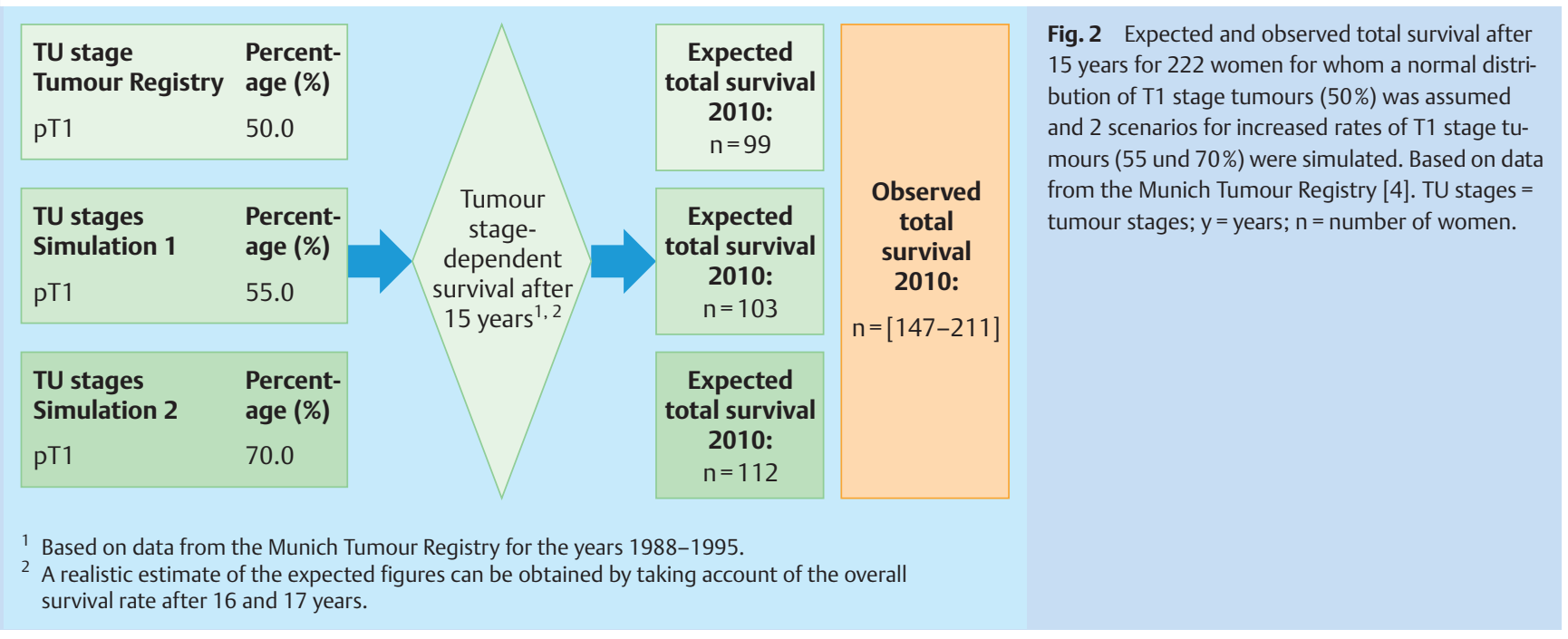

As the distribution of tumour stages showed an above average number of early tumour stages (tumour stages which have a better prognosis) among the affected women, an additional analysis with a higher percentage of $\mathrm{T} 1$ stage tumours was carried out (- Fig. 2). Using a simulation with a share of $55.0 \%$ pT1 a total of 103 women could have been expected to survive. Using a simulation with a share of $70 \%$ pT1 the total number of women expected to survive was 112 . However the observed total number of women who survived in our study was at least 147 and thus much higher.

\section{Tumour progression}

At the 10-year follow-up, 9 of the 222 (4.1\%) women on record reported disease progression. At the 15-year follow-up no new cases of recurrence or metastasis were noted. One woman with metastases at the time of the 10-year follow-up had died in the interim period, so that the total number of women with tumour progression remained the same ( 0 Table 2 ). By comparison, the expected number of women with disease progression using data from the long-term study of the Munich Tumour Registry would have been 29 (13\%) out of 222 women.

In a sensitivity analysis it was additionally assumed that disease progression would have occurred in $13 \%$ of the 64 women for whom we were unable to obtain information for our study. Thus $17.3 / 222(7.7 \%)$ women would have had tumour progression
Da die Stadienverteilung bei den betroffenen Frauen einen überdurchschnittlichen Anteil an niedrigen Tumorstadien mit besserer Prognose aufwies, erfolgte zusätzlich eine Analyse mit einem höheren Anteil an T1-Stadien ( $\triangle$ Abb. 2). Bei der Simulation mit einem Anteil von 55,0\% pT1 betrug das zu erwartende Überleben 103 Frauen. Bei einer Simulation mit einem Anteil von $70 \%$ pT1 betrug das zu erwartende Überleben 112 Frauen. Das beobachtete Gesamtüberleben war jedoch in dieser Studie mit mindestens 147 Frauen deutlich höher.

\section{Tumorprogressionen}

In der 10-Jahres-Verlaufskontrolle lag bei 9 der 222 (4,1\%) aktenkundigen Frauen eine Tumorprogression vor. In der 15-JahresVerlaufskontrolle wurde kein neues Auftreten von Rezidiven oder Metastasen beobachtet. Eine Frau mit Metastasen in der 10-Jahres-Verlaufskontrolle verstarb in der Zwischenzeit, sodass die Gesamtzahl der Frauen mit Tumorprogression gleich geblieben ist ( Tab. 2). Im Vergleich dazu liegt die erwartete Progression nach den Daten der Langzeitstudie des Tumorregisters München bei 29 von 222 (13\%) Frauen.

In einer Sensitivitätsanalyse wurde darüber hinaus angenommen, dass bei $13 \%$ der 64 Frauen, von denen in unserer Studie keine Informationen vorlagen, eine Progression vorliegt. Somit wären 17,3/222 (7,7\%) Frauen von einer Progression betroffen gewesen ( Tab. 6), was immer noch unter der erwarteten Zahl 
Table 6 Expected and observed disease progression in 222 women after 15 years. Expected progression based on data from the Munich Tumour Registry.

\begin{tabular}{|lcc|}
\hline & N & $\%$ \\
\hline Total numbers & 222 & 100 \\
\hline Expected progression* & 29 & 13.0 \\
\hline Observed progression & 9 & 4.1 \\
\hline Medium scenario** $^{*}$ & 17.3 & 7.7 \\
\hline Worst scenario** $^{*}$ & 73 & 32.8 \\
\hline
\end{tabular}

Women with progression in the Munich Tumour Registry Specific Analysis 19782007 (http://www.tumorregister-muenchen.de/facts/specific_analysis.php). Over a period of 29 years, a total of 8621 of 34478 tumour patients had tumour progression. This corresponds to a progression rate of $13 \%$ over 15 years.

** For the medium scenario it was assumed that $13 \%$ (cf. expected progression) of the 64 women about whom no information could be obtained had disease progression. Based on this assumption $(13 / 100 \times 64=8.3)$, in the medium scenario the expected number of women with progression would be $8.3+9=$ 17.3. For the worst scenario we assumed that all 64 women about whom we could not obtain information had disease progression.

( Table 6), a figure which was still less than the expected number of women with disease progression. Only a worst-case scenario which assumed that all of the 64 women for whom no information was obtainable suffered progression resulted in a distinctly higher number of women with progression than expected.

\section{Female offspring}

A total of 72 (49\%) out of 147 women gave birth to at least 1 daughter. In all, 99 daughters were born. Average age of the daughters at the time of the 15-year follow-up was 38.2 years (range: 18-51 years). No information was available for 9 daughters. Two (2.2\%) out of 90 daughters for whom we have information (ages: 36 years and 50 years) were diagnosed with breast cancer. The mothers of these daughters had no familial predisposition. In a medium scenario it was assumed that the expected incidence of breast cancer for all of the 9 daughters about whom we have no information was $10 \%$. Using this assumption we calculated an expected incidence of 2.9 cases with breast cancer (2.9\%) among the daughters in our study ( $\bullet$ Table 7 ). This was compared to the average incidence in Germany for daughters of mothers with breast cancer who were also diagnosed with breast cancer, based on figures from the German Cancer Research Centre (DKFZ), of between 5 and 10\% [5,6]. The expected calculated age-specific incidence among the general population for daughters with a positive familial diagnosis was 2.7, a figure which is only slightly higher than the number of cases observed $(\mathrm{n}=2)$ ( Table 8). von Progressionen liegt. Lediglich im schlechtesten Szenario, das davon ausgeht, dass alle 64 Frauen, von denen keine Informationen vorlagen, eine Progression hatten, ist mit einer deutlich höheren Zahl von Progressionen zu rechnen als erwartet.

\section{Weibliche Nachkommen}

72/147 (49\%) Frauen hatten mindestens 1 Tochter geboren. Insgesamt hatten sie 99 Töchter geboren. Das mittlere Lebensalter der Töchter war zum Zeitpunkt der 15-Jahres-Verlaufskontrolle 38,2 Jahre (18-51 Jahre). Über 9 Töchter haben wir keine Informationen. 2/90 (2,2\%) Töchter, über die wir Informationen haben (Alter: 36 Jahre und 50 Jahre) erkrankten an einem Mammakarzinom. Beide Mütter dieser Töchter hatten keine familiäre Vorbelastung. Im mittleren Szenario wurde angenommen, dass bei allen 9 Töchtern, von denen keine Informationen vorlagen, die erwartete Rate an Mammakarzinomen 10\% ist. Demnach werden in unserer Studie 2,9 Mammakarzinome (2,9\%) bei den Töchtern errechnet ( Tab. 7). Im Vergleich beträgt der deutschlandweite Durchschnitt von Töchtern mit Müttern mit Mammakarzinom, die auch an einem Mammakarzinom erkranken, nach dem Deutschen Krebsforschungszentrum (DKFZ) zwischen 5-10\% [5,6]. Die aus der alterspezifischen Inzidenz der Allgemeinbevölkerung errechnete erwartete Zahl der Fälle bei den Töchtern mit positiver Familienanamnese beträgt 2,7, was geringfügig über der beobachteten Zahl der Fälle ( $n=2)$ liegt ( $\bullet$ Tab. 8).

\section{Finanzielle Entschädigung der Frauen}

91/147 (62\%) Frauen haben eine finanzielle Entschädigung der Haftpflichtversicherung des Pathologen erhalten. Die letzte Zahlung fand durchschnittlich 12,7 Jahre nach dem Ereignis statt. Die finanzielle Entschädigung ist bis heute nicht abgeschlossen. Die Entschädigung der Frauen, die Anklage erhoben hatten, erfolgte gestaffelt in Hinblick auf die Anzahl der betroffenen Frauen pro Jahr und unter Berücksichtigung der Ausdehnung des operativen Eingriffs. 56/147 (38\%) Frauen haben keine Entschädigung erhalten, da sie keine Anklage erhoben hatten.

\section{Diskussion}

\section{$\nabla$}

Bis heute ist ungeklärt, bei wie vielen Frauen aus Essen in den Jahren 1993-1996 durch den Pathologen tatsächlich eine falsche Brustkrebsdiagnose gestellt wurde. Das Ziel dieser Studie war daher, durch eine Verlaufskontrolle nach 15 Jahren herauszufinden, ob sich die Ergebnisse der 10-Jahres-Verlaufskontrolle bestätigen. In dieser Analyse zeigte sich, dass mehr betroffene Frauen überlebt haben als erwartet und dass die Anzahl an Rezidiven und/ oder Metastasen und Tod durch Mammakarzinom geringer war

Table 7 Number of daughters with breast cancer compared to data from the German Cancer Research Centre (DKFZ).

\begin{tabular}{|c|c|c|}
\hline Scenarios & Number & Percentage \\
\hline Observed figures & $2 / 90$ & $2.2 \%$ \\
\hline Best scenario: all daughters about whom we have no information do not have breast cancer & 2/99 & $2.0 \%$ \\
\hline Medium scenario* & 2.9/99 & $2.9 \%$ \\
\hline Worst scenario** & $11 / 99$ & $11.1 \%$ \\
\hline Average for all of Germany** : daughters of mothers with breast cancer who also have breast cancer & $5-10 / 100$ & $5.0-10.0 \%$ \\
\hline
\end{tabular}

* In the medium scenario it was assumed that $10 \%$ of the 9 daughters about whom no information could be obtained had breast cancer. Based on this assumption $(9 / 100 \times 10=0.9)$, in the medium scenario it was calculated that a total of $0.9+2=2.9$ daughters would have breast cancer. In the worst scenario we assumed that all 9 daughters about whom no information could be obtained had breast cancer.

** Cancer information service of the German Cancer Research Centre (DKFZ), Krebsinformationsdienst [5] and McPherson et al. [6]. 
Financial compensation for the women

A total of 91/147 (62\%) of the women received financial compensation from the pathologist's liability insurance. The last payment was made an average of 12.7 years after the event. The paying of compensation to affected women has not yet been finally concluded. Compensation payments to the women who filed an action have been made over a period of time and has depended on the number of women affected per year and the extent of the operative intervention. Fifty-six of the 147 (38\%) women have received no compensation as they did not bring charges.

\section{Discussion}

$\nabla$

It is still not known how many women in Essen were actually wrongly diagnosed with breast cancer in the years 1993-1996 by the pathologist. The aim of this study was therefore to find out, based on a follow-up examination after 15 years, whether the results of the 10-year follow-up would be confirmed. Our analysis showed that more affected women survived than expected and that the numbers of women with recurrence and/or metastasis and the number of deaths due to breast cancer were lower than expected. In addition, the study investigated how many of these women had given birth to daughters and how many of the daughters had been diagnosed with breast cancer.

The results of the follow-up after 15 years show that more women survived than expected and that the numbers of women with recurrence and/or metastasis and the number of deaths due to breast cancer were lower than expected. This confirms the results of our 10-year follow-up. In addition, we found that fewer daughters of affected women had been diagnosed with breast cancer than expected.

These results support the suspicion that not all women diagnosed by the pathologist in Essen did indeed have breast cancer. At the 15-year follow-up we noted a total survival rate for these women of $93.0 \%$, which is much higher than the $45 \%$ calculated using the Munich Tumour Registry [3,4]. Even calculations based on a worst prognosis scenario, whereby all women about whom we were unable to obtain further information had breast cancer, resulted in a total survival rate of $66.2 \%$ which was still higher than that of the Munich Tumour Registry (45\%). Similarly, we noted a higher total survival rate among the affected women, even taking higher numbers of early stage tumours in this collective into consideration compared to the figures from the field study of the Munich Tumour Registry [3,4]. The results of the 15-year follow-up confirmed the results of the 10-year followup [1], and thus confirmed the suspicion that a number of false diagnoses were made.

In our follow-up investigations after 10 and 15 years, the recorded number of women with tumour progression was 9 (4.1\%) out of 222 cases, and thus far below the expected numbers for women with tumour progression based on the long-term study of the Munich Tumour Registry, which calculated a rate of $13 \%$ [4]. Calculations using a medium scenario, where it was assumed that $13 \%$ of the 64 women about whom we were unable to obtain information would have disease progression, resulted in a progression of 17.3/222 (7.7\%) which was still far below the rate of $13 \%$ calculated using the Munich Tumour Registry [4]. These results again confirm the suspicion that false-positive diagnoses were made. But it is still impossible to make a definitive statement regarding individual cases. Moreover, it should be remembered that these women could have breast cancer or a secondary
Table 8 Comparison between the expected numbers of daughters with breast cancer and the actual numbers observed.

\begin{tabular}{|l|l|}
\hline Year & $\begin{array}{l}\text { Expected numbers } \\
\text { of daughters with } \\
\text { breast cancer* }\end{array}$ \\
\hline $1(2010)$ & 0.09 \\
\hline $2(2009)$ & 0.10 \\
\hline $3(2008)$ & 0.10 \\
\hline $4(2007)$ & 0.12 \\
\hline $5(2006)$ & 0.12 \\
\hline 6 (2005) & 0.14 \\
\hline $7(2004)$ & 0.14 \\
\hline 8 (2003) & 0.15 \\
\hline $9(2002)$ & 0.17 \\
\hline $10(2001)$ & 0.17 \\
\hline 11 (2000) & 0.16 \\
\hline 12 (1999) & 0.17 \\
\hline $13(1998)$ & 0.23 \\
\hline $14(1997)$ & 0.27 \\
\hline $15(1996)$ & 0.29 \\
\hline 15 -year cumulative incidence & 2.42 \\
\hline Corrected by a factor of 10\% for the & 0.24 \\
\hline cumulative incidence* & \\
\hline 15 -year expected cumulative cases & $\mathbf{2 . 6 6}$ \\
\hline Observed 15-year cumulative cases & $\mathbf{2 . 0 0}$ \\
\hline Calculated per year based on cases in Münster (15 years: $1994-2008$, Münster \\
\hline Cancer Registry) & \\
\hline ** Cancer information service of the German Cancer Research Centre (DKFZ), \\
\hline Krebsinformationsdienst [5] and McPherson et al. [6]. \\
\hline
\end{tabular}

als erwartet. Zusätzlich wurde in dieser Arbeit ermittelt, wie viele der Frauen Töchter geboren hatten und wie viele der Töchter an einem Mammakarzinom erkrankt sind.

Die Ergebnisse unserer 15-Jahres-Verlaufskontrolle zeigen, dass mehr Frauen überlebt haben als erwartet und dass die Anzahl an Rezidiven und/oder Metastasen und Tod durch Mammakarzinom geringer war als erwartet. Dies entspricht somit den Ergebnissen unserer 10-Jahres-Verlaufskontrolle. Darüber hinaus konnten wir feststellen, dass weniger Töchter der betroffenen Frauen an einem Mammakarzinom erkrankt waren als erwartet. Diese Ergebnisse unterstützen die Vermutung, dass nicht alle Frauen bei Diagnosestellung durch den Pathologen in Essen tatsächlich an einem Mammakarzinom erkrankt waren.

Wir konnten in der 15-Jahres-Verlaufskontrolle ein beobachtetes Gesamtüberleben der Frauen von 93,0\% beobachten, welches deutlich über dem des Tumorregisters München von $45 \%$ lag [3, 4]. In der schlechtesten Prognose, in der angenommen wurde, dass alle Frauen, von denen wir keine Informationen haben, an einem Mammakarzinom erkrankt sind, ergab sich mit 66,2\% ebenfalls eine höhere Gesamtüberlebensrate als die des Tumorregisters München (45\%). Ebenso konnten wir bei den betroffenen Frauen unter Berücksichtigung der höheren Anzahl früherer Tumorstadien im Vergleich zur Feldstudie des Tumorregisters München ein höheres beobachtetes Gesamtüberleben feststellen als erwartet [3,4]. Somit bestätigen die Ergebnisse der 15-JahresVerlaufskontrolle unsere Ergebnisse der 10-Jahres-Verlaufskontrolle [1], und folglich unterstützen diese Ergebnisse die Vermutung, dass ein Anteil von Fehldiagnosen bestanden hat.

In unserer 10- und 15-Jahres-Verlaufskontrolle lag der Anteil der Tumorprogressionen mit 9/222 (4,1\%) aktenkundigen Frauen deutlich unter der erwarteten Progression der Langzeitstudie des Tumorregisters München von 13\% [4]. Im mittleren Szenario, 
carcinoma just like anybody else in the general public. We are therefore of the opinion that the affected women should continue to be followed up and be screened for cancer.

We found that the number of daughters with breast cancer, a total of $2(2.2 \%)$ out of 90 , was far below that of the average rate for daughters of women with breast cancer in Germany (5-10\%) [5, $6]$. A sensitivity analysis, in which it was assumed that $10 \%$ of the daughters about whom we have no information, had breast cancer, still resulted in a rate which was lower than the average rate calculated for all of Germany. This confirms the suspicion that these daughters had no familial genetic predisposition. However, the uncertainty of the daughters in individual cases as to whether there may be a familial predisposition still exists. The question therefore arises whether these daughters require intensive early screening and information, both of which could be provided by breast centres.

We found that the financial compensation payments were still not settled in all cases, even after 10 years. The amount paid out by the pathologist's liability insurance was based on the extent of the operative intervention (breast-conserving therapy vs. mastectomy) and the number of affected or operated women in the respective years between 1993 and 1996. A higher number of affected women in one year results in a lower financial compensation paid out by the pathologist's liability insurance to the affected individuals.

In our opinion, these women still require further individually modified, early cancer screenings together with other rehabilitation measures. It would be preferable if the state provided the affected women with this care without these women being required to pay additional costs.

In the meantime, a number of certified breast centres have opened; these breast centres are obliged to comply with quality management standards and to carry out an extensive, cross-specialty documentation of patient data which may prevent such events as those which affected the women of this study from occurring in future [7].

The optimal diagnostics and therapy of patients with breast cancer requires an inter-disciplinary co-operation between radiologists, gynaecologists and/or surgeons, pathologists, oncologists, and radiation therapists. The close co-operation between different specialties in breast centres offers the best diagnostic and therapeutic opportunities and ensures that patients will receive a treatment that complies with national and international guidelines and is state-of-the-art.

\section{Conclusions}

\section{$\nabla$}

The results of our 15-year follow-up show that more women survived than expected and that the numbers of women with recurrence and/or metastasis and the numbers of deaths due to breast cancer were also lower than expected. This confirms the results of our 10-year follow-up investigation. Moreover we also noted that fewer daughters of affected women were diagnosed with breast cancer than expected.

These results support the suspicion that not all of the women diagnosed with breast cancer by the pathologist in Essen had breast cancer. in dem angenommen wurde, dass von den 64 Frauen, von denen wir keine Informationen haben, 13\% eine Progression aufweisen, ergab sich mit 17,3/222 (7,7\%) ebenfalls eine Progressionsrate weit unter den Ergebnissen des Tumorregisters München (13\%) [4]. Dies Ergebnisse unterstützen ebenfalls die Vermutung, dass falsch positive Diagnosen gestellt worden waren. Eine Aussage für den Einzelfall ist jedoch weiterhin nicht möglich. Darüber hinaus ist zu bedenken, dass diese Frauen wie die Allgemeinbevölkerung an einem Mammakarzinom bzw. Zweitkarzinom erkranken könnten. Daher sollten die betroffenen Frauen aus unserer Sicht weiterhin an einer Nachsorge bzw. Krebsvorsorge teilnehmen.

Wir konnten feststellen, dass der Anteil der Töchter, die an einem Mammakarzinom erkrankt sind, mit 2/90 (2,2\%) unter dem deutschlandweiten Durchschnitt von Töchtern mit Müttern mit Mammakarzinom lag (5-10\%) [5,6]. In einer Sensitivitätsanalyse, in der angenommen wurde, dass $10 \%$ der Töchter, von denen wir keine Informationen haben, an einem Mammakarzinom erkrankt sind, ergab sich ebenfalls eine Rate unter dem deutschlandweiten Durchschnitt. Dies unterstützt die Vermutung, dass bei den Töchtern keine eindeutige familiäre Vorbelastung vorliegt. Die Unsicherheit der Töchter im Einzelfall, ob eine familiäre Vorbelastung vorliegt, ist jedoch weiterhin vorhanden. Es stellt sich daher die Frage, ob diese Töchter eine intensive Früherkennung und Aufklärung benötigen, die durch Brustzentren erfolgen könnte.

Wir konnten feststellen, dass die finanzielle Entschädigung der Frauen noch nach über 10 Jahren nicht abgeschlossen war. Die Höhe der finanziellen Entschädigung durch die Haftpflichtversicherung des Pathologen richtet sich nach dem Ausmaß des operativen Eingriffs (brusterhaltende Therapie vs. Ablatio mammae) und nach der Anzahl der betroffenen bzw. operierten Frauen in den jeweiligen Jahren 1993-1996. Je höher der Anteil der betroffenen Frauen pro Jahr, desto geringer ist die finanzielle Entschädigung der jeweiligen Betroffenen durch die Haftpflichtversicherung des Pathologen.

Aus unserer Sicht erfordern diese Frauen weitere individuell modifizierte Krebsfrüherkennungsuntersuchungen und weitere Rehabilitationsmaßnahmen. Es wäre daher wünschenswert, dass diese Maßnahmen den betroffenen Frauen durch den Staat ohne zusätzlichen Kostenaufwand zur Verfügung gestellt werden.

Durch die in der Zwischenzeit erfolgte Einrichtung und Zertifizierung von Brustzentren mit der Verpflichtung zu einem Qualitätsmanagement und zu einer umfassenden, sektorübergreifenden Dokumentation der Daten der Patientinnen können Ereignisse, wie sie im Falle der betroffenen Frauen geschehen sind, möglicherweise in Zukunft verhindert werden [7].

Eine optimale Diagnostik und Therapie bei Patientinnen mit Mammakarzinom erfordert eine interdisziplinäre Zusammenarbeit zwischen Radiologen, Gynäkologen und/oder Chirurgen, Pathologen, Onkologen und Strahlentherapeuten. Diese enge Kooperation der verschiedenen Fachdisziplinen, wie sie in Brustzentren gefordert und angeboten wird, ermöglicht die optimale Ausnutzung der diagnostischen und therapeutischen Möglichkeiten und garantiert eine Behandlung, welche auf nationalen wie internationalen Leitlinien beruht und dem neuesten Stand der Wissenschaft entspricht. 


\section{Conflict of Interest}

None.

\section{References}

1 Hauth EAM, Hoffmann B, Jäger $H$ et al. Epidemiologische und kernspintomographische Verlaufskontrolle 10 Jahre nach vermutlich falscher Diagnose Brustkrebs. Senologie 2006; 3: 1-8

2 Deutsche Gesellschaft für Senologie - Der Vorstand. Zusammenfassende Stellungnahme zu den von der Interessengemeinschaft „Diagnose Brustkrebs“ angeforderten Gutachten. Marburg 4.1.2000, 1-8

3 Gutschow K, Artmann A, Astner S et al. Nachsorge. In: Sauer H, Hrsg. Manual Mammakarzinome. Empfehlungen zur Diagnostik, Therapie und Nachsorge. 10. Auflage. München: Tumorzentrum München, W. Zuckerschwerdt Verlag; 2005: 153-166

4 Tumorregister München. Specific analysis 1978-2007. http://www. tumorregister-muenchen.de/facts/specific_analysis.php; last access: 2011

5 Deutsches Krebsforschungszentrum (DKFZ), Krebsinformationsdienst. http://www.krebsinformationsdienst.de/tumorarten/brustkrebs/ brustkrebsrisiken-persoenlich.php; last access: 2008

6 McPherson K, Stell CM, Dixon JM. Breast cancer-epidemiology, risk factors, and genetics. BMJ 2000; 321: 624-628

7 Bamberg M, Wallwiener D, Kreienberg R. Zertifizierung von Brustzentren. Gemeinsame Stellungnahme der Deutschen Gesellschaft für Senologie, der Deutschen Krebsgesellschaft, der Deutschen Gesellschaft für Gynäkologie und Geburtshilfe und des Krebsverbandes Baden-Württemberg. Geburtsh Frauenheilk 2004; 64: 1155-1157

Deutschsprachige Zusatzinformationen online abrufbar unter: www.thieme-connect.de/ejournals/toc/gebfra.

\section{Schlussfolgerungen}

Die Ergebnisse unserer 15-Jahres-Verlaufskontrolle zeigen, dass mehr Frauen überlebt haben als erwartet und dass die Anzahl an Rezidiven und/oder Metastasen und Tod durch Mammakarzinom geringer war als erwartet Dies bestätigt somit die Ergebnisse unserer 10-Jahres-Verlaufskontrolle. Darüber hinaus konnten wir feststellen, dass weniger Töchter der betroffenen Frauen an einem Mammakarzinom erkrankt waren als erwartet.

Diese Ergebnisse unterstützen die Vermutung, dass nicht alle Frauen bei Diagnosestellung durch den Pathologen in Essen an einem Mammakarzinom erkrankt waren.

\section{Interessenkonflikt}

$\nabla$

Für die Autoren besteht kein Interessenkonflikt. 